\title{
PRESTAÇÕES ACESSÓRIAS, PRESTAÇÕES SUPLEMENTARES E SUPRIMENTOS ${ }^{1}$
}

\author{
Helena Salazar* \\ Margarida Azevedo** \\ Nuno Alonso Paixão***
}

\section{Introdução}

Neste estudo propomo-nos proceder a uma abordagem jurídico-societária e jurídico-fiscal das figuras das prestações acessórias suplementares e suprimentos, enquanto instrumentos de financiamento das sociedades comerciais.

0 financiamento das sociedades comerciais pelos sócios constitui a finalidade das prestações suplementares e dos suprimentos.

10 presente artigo baseia-se na Aula Aberta, intitulada "Prestações suplementares, acessórias e suprimentos. Reflexão jurídica e contabilística", na sua vertente jurídica. 0 seu conteúdo beneficiou das observações do nosso Colega da área científica de Contabilidade, Senhor Dr. Rui Saavedra, que tivemos o gosto de ter ao nosso lado como orador e a quem muito agradecemos.

* Mestre em Direito pela Faculdade de Direito da Universidade de Coimbra. É Professora Adjunta no Instituto Superior de Contabilidade e Administração do Porto. É Advogada, Formadora do Conselho Regional do Porto da Ordem dos Advogados e de outras organizações profissionais. (hsalazar@iscap.ipp.pt)

** Doutorada pela Faculdade de Direito da Universidade de Coimbra, na área de especialização de Ciências Jurídico-Empresariais. É Professora Adjunta do Instituto Superior de Contabilidade e Administração. É Advogada, tendo vindo a participar em trabalhos de consultoria. (margaridaazevedo15@gmail.com)

*** Licenciado e mestre em Direito pela Faculdade de Direito da Universidade do Porto. Encontra-se atualmente inscrito no Curso de Doutoramento em Direito na mesma instituição. Assistente convidado na Escola do Porto da Faculdade de Direito da Universidade Católica Portuguesa. Assistente convidado no Instituto Superior de Contabilidade e Administração do Porto - Instituto Politécnico do Porto. Advogado. (n.paixao@sapo.pt) 
Também as prestações acessórias poderão servir o objectivo de financiamento da sociedade? .

Com efeito, as obrigações acessórias poderão ser de natureza pecuniária, nomeadamente assumindo a veste de obrigações de empréstimo do sócio à sociedade quer sob a forma de mútuos, quer sob a forma de suprimentos.

Discutível é a possibilidade de as prestações acessórias de empréstimo se apresentarem como financiamentos do sócio à sociedade sujeitos ao regime jurídico das prestações suplementares, em particular em matéria de reembolso. A este expediente é reconhecida grande utilidade nas sociedades anónimas como forma de ultrapassar a falta de previsão de financiamento através do recurso a prestações suplementares ${ }^{3}$.

Esta questão representa o núcleo central de análise na parte jurídico-societária deste artigo.

Para compreensão do problema, torna-se necessário conhecer cada uma destas figuras. Analisaremos, neste sentido, os respectivos conceitos, finalidades específicas e os seus reflexos no regime jurídico de cada uma. É esta a abordagem societária da questão.

\footnotetext{
2 Isto embora as prestações acessórias de natureza pecuniária se afastem do tipo de obrigações que desencadearam esta figura. As obrigações de prestações acessórias surgiram na Alemanha, como forma de assegurar o fornecimento de matéria prima dos sócios à sociedade. Sobre o assunto, v., por todos, Alexandre Mota Pinto, Anotações aos arts $209^{\circ}$ do Código da Sociedades Comerciais. In Jorge Manuel Coutinho de Abreu (coord.). "Código das Sociedades Comerciais em Comentário" . Vol, III. Coimbra: Almedina, 2016, p. 267, nota 2. Também anotações aort. $287^{\circ}$, in Jorge Manuel Coutinho de Abreu (coord.). Código das Sociedades Comerciais em Comentário. Vol V, Coimbra; Almedina, p. 173, nota 2.

Sobre a evolução histórica na lei portuguesa, veja-se Rui Pinto Duarte, Prestações suplementares e Prestações Acessórias (uma reincidência). In "Nos 20 Anos do Código das Sociedades Comerciais". Coimbra: Coimbra Editora, 2007, pp. 696 e segs.

3 Pondo em evidência a incoerência resultante do facto de o legislador não ter consagrado as prestações suplementares nas sociedades anónimas e de idêntico resultado poder ser obtido por meio de prestações acessórias, Rui Pinto Duarte, Prestações Suplementares ...cit., p. 705.
} 


\section{Tratamento jurídico-societário das figuras}

\subsection{As prestações acessórias}

As prestações acessórias são obrigações eventuais dos sócios perante a sociedade. A sua natureza eventual deriva da circunstância de não serem impostas pela lei, mas assumidas no contrato de sociedade.

Trata-se, pois, de uma obrigação do sócio perante a sociedade. Identifica-se, portanto, como uma obrigação social e não como um mero acordo lateral do sócio com a sociedade 4 .

Assim se compreende que estas obrigações acompanhem, em regra, a transmissão das participações sociais. Na realidade, tal só não acontecerá se as prestações tiverem sido assumidas em função das qualidades pessoais do sócio obrigado (prestações infungíveis) ${ }^{5}$.

Embora sejam verdadeiras obrigações sociais, isto é, ligadas à qualidade de sócio, a verdade é que estão sujeitas a um regime jurídico em vários aspectos muito diverso dos que regem outras obrigações patrimoniais perante a sociedade, como a obrigação de entrada e as prestações suplementares de capital. Com efeito, o regime jurídico das prestações acessórias é delineado em função da ideia de que o sócio que cumpra uma obrigação acessória, adquirindo um direito patrimonial sobre a sociedade ${ }^{6}$, é tratado como um credor.

Vejamos mais de perto o que poderá constituir objecto de prestações acessórias.

As prestações acessórias são obrigações assumidas pelos sócios perante a sociedade e podem revestir conteúdos muito variados. Poderão ir desde, por exemplo, obrigações de prestação de serviços, passando por obrigações de empréstimo e de fornecimento de bens,

\footnotetext{
4 Sublinhando a importância do facto de as prestações acessórias revestirem a qualidade de obrigações sociais, Alexandre Mota Pinto, Anotações ao arts $209^{\circ}$ do Código da Sociedades Comerciais ...cit., p. 267 nota 2.

5 Veja-se, neste sentido, Coutinho de Abreu, Curso de Direito Comercial. Coimbra Almedina, 2015, pp. 300. Alexandre Mota Pinto, Anotação ao art. 209 ...cit., p. 272.

6 Poderá consistir no direito de crédito derivado da natureza onerosa da obrigação acessória.
} 
até obrigações de não concorrência. Assim, são-Ihes aplicáveis as regras dos contratos típicos que tenham celebrado com a sociedade (arts. 209\% 1 , parte final e 287\% 1 , parte final ambos do CSC).

Os elementos essenciais das obrigações devem estar presentes no contrato de sociedade, de modo a que o sócio a elas vinculado conheça o alcance das obrigações. Na realidade, as prestações acessórias são admitidas nas sociedades anónimas, por quotas e em comandita por acções. Nas sociedades anónimas, os sócios apenas participam no risco da exploração da sociedade na medida do valor das respectivas entradas, o mesmo se passando com os sócios comanditários das sociedades em comandita.

Nas sociedades por quotas, em princípio, os sócios tomam parte no risco da sociedade apenas no valor da realização das entradas na sociedade. Daí que o alcance das obrigações acessórias a que o sócio se comprometeu deva estar determinado ou se deva poder determinar a partir dos elementos presentes no contrato de sociedade?

Entrando no respectivo regime jurídico, em vários dos seus aspectos, vemos reflectida a ideia de que, pese embora o facto de se tratar de verdadeiras obrigações sociais, a sociedade e sócio são tratados como partes em um contrato.

Deste modo, desde logo, ao incumprimento de uma obrigação acessória não vão, em princípio, associadas consequências na posição de sócio, aplicando-se antes as regras gerais sobre o incumprimento das obrigações ${ }^{8}$. Na verdade, salvo disposição em contrário do contrato de sociedade, a posição do sócio não poderá ser prejudicada, quer no que respeita à sua permanência na sociedade, quer no que concerne aos seus direitos perante a sociedade (arts. 209\%/4 e 287\%/4 CSC ] ${ }^{9}$.

Quando as prestações assumam natureza onerosa, a contrapartida poderá ser retirada de fundos não distribuíveis ${ }^{10}$, o que se com-

\footnotetext{
? Veja-se, desenvolvidamente, Coutinho de Abreu, Curso de Direito Comercial ...cit., p. 298.

8 Coutinho de Abreu, Curso de Direito Comercial ...cit, p. 300.

9 Alexandre Mota Pinto, Anotação ao art. $209^{\circ}$...cit., p. 271.

10 Esta conclusão resulta dos arts. 209\%/3 e 287\%/3 CSC ao referirem que a contraprestação devida pela sociedade pelo cumprimento de obrigações acessórias poderá ser satisfeita
} 
preende pelo facto de os sócios actuarem na veste de credores e não estritamente de sócios.

Deste modo, se, por exemplo, um sócio prestar serviços em favor da sociedade, tendo sido convencionada a onerosidade da obrigação acessória de prestação de serviços, a contrapartida poderá ser satisfeita pela sociedade, ainda que esta não disponha no momento de bens distribuíveis. Do forma idêntica, se o sócio tiver emprestado dinheiro à sociedade, caso a obrigação acessória de empréstimo assuma natureza onerosa, as quantias necessárias ao pagamento de juros poderão ser retiradas de fundos não distribuíveis.

Se assim é quanto ao pagamento de juros, não subsistem dúvidas de que, pelo menos em regra, o mesmo deverá acontecer quanto à obrigação de reembolso. Com efeito, as quantias necessárias ao reembolso poderão ser extraídas de verbas necessárias à cobertura do capital social e das reservas indisponíveis, uma vez que os sócios actuam na qualidade de credores da sociedade, não estando limitados pelo princípio da intangiblidade do capital social. Aqui se revela uma importante diferença em relação às obrigações de entrada e às

ainda que não exista lucro de exercício. A lei, na realidade terá pretendido dizer que o valor da contraprestação poderá ser pago ainda que não exista lucro de balanço, isto é, ainda que não existam bens distribuíveis (assim, Alexandre Mota Pinto, Anotações ao art.. 209 ...cit. p. 270, Coutinho de Abreu, Curso de Direito Comercial ...cit., p. 302, Raul Ventura, Sociedade por Quotas. Vol.ll. Comentário ao Código das Sociedades Comerciais. Coimbra: Almedina, 1989, p. 205. 0 lucro de exercício consiste na diferença entre o património líquido da sociedade no final de um exercício e o património líquido da sociedade no início do exercício. Já o lucro de balanço corresponde aos bens distribuíveis, consistindo na diferença entre o património líquido da sociedade em dado momento e a soma do capital social e das reservas indisponíveis. Por outras palavras não podem ser destinados aos sócios bens necessários à cobertura do capital social e das reservas obrigatórias. Trata-se de preservar o princípio da intangiblidade do capital social.

Assim os conceitos apresentam-se distintos, podendo existir lucro de exercício sem que a sociedade disponha de lucro de balanço e vice-versa.

Concordamos que o legislador nos referidos arts. 209\%/3 e 287\%/3 CSC terá querido referir ao lucro de balanço e não o lucro de exercício. De facto, o que se pretende é, como explicámos em texto, é tratar o sócio como credor.

Sobre a distinção entre lucro de balanço e lucro de exercício veja-se Paulo Tarso Domingues, Capital e Património Sociais, Lucros e Reservas. In Jorge Manuel Coutinho de Abreu (coord.). "Estudos de Direito das Sociedades". Coimbra. Almedina, 2015, pp.201 a 203. 
obrigações de prestações suplementares. As entradas não poderão ser restituídas durante a vida da sociedade, a não ser que ocorra uma redução do capital social. Por seu turno, as quantias desembolsadas pelos sócios como obrigações de prestações suplementares só poderão ser devolvidas aos sócios se a sociedade não estiver em situação de insolvência e se existirem bens susceptíveis de serem distribuídos pelos sócios, ou seja, que não afectem a cobertura do capital social e das reservas indisponíveis.

Por outro lado, a exigência em concreto das prestações acessórias não depende de deliberação da Assembleia-Geral, cabendo esta decisão, em princípio, ao órgão de administração. Isto em sentido inverso ao que se passa com as prestações suplementares, cuja exigência compete à órgão deliberativo por excelência.

As obrigações acessórias estão sujeitas, pois, a um regime jurídico que assenta numa dupla vertente. Por um lado, são obrigações sociais, não resultando de meros acordos laterais entre o sócio e a sociedade. Por outro lado, estão sujeitas a um regime essencialmente contratual. Esta circunstância implica que o sócio seja tratado como credor quando do contrato para ele resultem direitos sobre a sociedade.

\subsection{As prestações suplementares}

As prestações suplementares constituem igualmente obrigações sociais. Diversamente das obrigações acessórias, apenas podem ter dinheiro por objecto, isto é, são necessariamente de natureza pecuniária.

A sua função consiste em permitir o aumento do património líquido (capital próprio) da sociedade, sem necessidade de um aumento do capital social ${ }^{11}$. Integrando as prestações sociais o capital próprio da sociedade, os sócios que efectuem prestações suplememtares em favor da sociedade não são tratados como credores, avul-

\footnotetext{
11 Veja-se, realçando esta circunstância, Alexandre Mota Pinto, Anotações ao art. $210^{\circ}$...cit., p. 277.
} 
tando a sua posição de sócios. Estes, também pela via das prestações suplementares, assumem o risco da exploração da sociedade.

Com a finalidade de limitar o risco a que se expõem os sócios, é elemento essencial de exigibilidade das prestações suplementares a referência no contrato de sociedade ao valor global.

0 estatuto social poderá identificar os sócios obrigados a efectuar prestações suplementares, bem como a contribuição a que cada sócio está obrigado. No entanto, caso estes aspectos não constem do pacto social, vigoram as normas supletivas que vão no sentido de considerar todos os sócios responsáveis e, onde a medida de participação de cada um seja omissa, os sócios devem concorrer nas prestações suplementares na proporção das respectivas participações no capital social.

0 regime jurídico reservado às prestações suplementares reflecte nitidamente a circunstância de as prestações suplementares não se identificarem com empréstimos.

Assim, a falta de cumprimento das prestações suplementares é tratada nos mesmos termos que o incumprimento da obrigação de entrada. Por conseguinte, a posição do sócio é afectada, podendo mesmo levar à sua exclusão nos termos previstos para a falta de cumprimento da obrigação de entrada (art. $212^{\circ} / 1$ CSC).

Na mesma linha de pensamento, as prestações suplementares nunca vencem juros (art. 210\%/5 CSC).

No que respeita à possibilidade de restituição das quantias desembolsadas pelos sócios, ela existe, mas sujeita a condições, previstas no art. $213^{\circ} \mathrm{CSC}$, que testemunham a circunstância de o sócio não assumir a posição de credor. A devolução das quantias pagas pelos sócios à sociedade como prestações suplementares depende da existência de bens distribuíveis no património da sociedade e da não verificação de declaração de insolvência. Note-se que existindo bens distribuíveis (e não tendo sido declarada a insolvência), as quantias destinadas ao pagamento de prestações suplementares só podem ser restituídas na medida do valor desses bens. Caso contrário, seria afectado o princípio da intangibilidade do capital social. 
Por outro lado, ainda que a sociedade esteja saudável do ponto de vista patrimonial e financeiro, o reembolso das prestações apenas poderá acontecer se merecer a aprovação da Assembleia-Geral, devendo ainda ser respeitado o princípio da igualdade entre os sócios ${ }^{12}$.

$\mathrm{Na}$ verdade, o facto de os sócios apenas poderem recuperar as quantias empregues se e na estreita medida em que existirem bens na sociedade que não sejam necessários à cobertura do capital social e da reserva legal harmoniza-se com a ideia de que as prestações suplementares envolvem um compromisso na prossecução do interesse social. No mesmo sentido vai a exigência de que a sociedade não esteja numa situação de insolvência. É igualmente manifestação deste comprometimento com o interesse da sociedade a circunstância de o reembolso das quantias dever ser decidida em Assembleia-Geral.

Assim sendo, as prestações suplementares são tidas contabilisticamente como capital próprio e não como capital alheio.

\subsection{Os suprimentos}

Os suprimentos identificam-se com empréstimos dos sócios à sociedade ou diferimentos de créditos dos sócios sobre a sociedade ${ }^{13}$, em que avulta o seu carácter de permanência. Quer isto dizer, que tendo por finalidade responder a necessidades estruturais da sociedade, revelam uma preocupação forte com o interesse da sociedade. Por isso, constitui índice de carácter de permanência o diferimento ou prazo de reembolso superior a um ano. Temos então, nestes casos, uma presunção ilidível de permanência. Não sendo a presunção afastada, o crédito está sujeito ao regime dos suprimentos.

\footnotetext{
12 Para além disso, é necessário que o sócio a quem as quantias são restituídas tenha realizado na totalidade a sua entrada.

13 Note-se que a falta de exigência de um crédito durante mais de um ano para o qual não tenha sido estipulado um prazo de reembolso ou este seja inferior a um ano, também constitui índice de permanência.
} 
Também por isso, apesar de os sócios que concedem suprimentos serem credores, o regime do respectivo reembolso coloca-os numa posição diferente dos outros credores, após os momentos de dissolução ou de declarada a insolvência da sociedade. Os credores de suprimentos apenas serão pagos depois de satisfeitos os restantes credores.

Quando os suprimentos resultem do contrato de sociedade, teremos uma verdadeira obrigação acessória, que se rege pelo regime do contrato de suprimento, conjugado com o previsto na lei quanto às prestações acessórias.

Consequentemente, o pagamento de juros que hajam sido acordados, bem como reembolso dos créditos não têm que ser feitos apenas à custa de bens distribuíveis. Também, ao contrário das prestações suplementares, os créditos sujeitos ao regime dos suprimentos podem ser satisfeitos após a declaração de insolvência, embora devam ceder prioridade aos restantes direitos de crédito e não possam ser objecto de compensação.

A razão de ser do tratamento especial dos credores de suprimentos, após a declaração de dissolução ou de insolvência da sociedade, deve ser compreendida à luz da finalidade dos suprimentos que, como vimos, consiste em auxiliar a sociedade a superar dificuldades estruturais. Ao conceder suprimentos, o sócio revela uma especial preocupação com o interesse social, o que se reflecte no seu regime jurídico.

Contudo, antes destes momentos, o credor de suprimentos é tratado como um credor normal, não impondo a lei que as quantias destinadas ao pagamento dos juros ou ao reembolso dos créditos sejam retiradas dos bens distribuíveis.

Com base nas especiais características dos créditos de suprimentos, Alexandre Mota Pinto sugere a sua classificação como capital quase próprio ${ }^{14}$.

14 Veja-se, designaamente, Anotações ao art. 209 ...cit., p. 275. 


\subsection{Possiblidade de sujeição de obrigações acessórias de emprés- timo ao regime das prestações suplementares nas sociedades anónimas?}

Depois de postas em evidência as linhas de orientação dos regimes jurídicos da prestações acessórias, prestações suplementares e suprimentos, resta-nos reflectir sobre a possibilidade de prestações suplementares nas sociedades anónimas por previsão directa no contrato de sociedade ou pela obtenção de um resultado idêntico por via da utilização da figura das prestações acessórias.

As prestações suplementares estão apenas previstas na lei para as sociedades por quotas. Não obstante, alguma doutrina tem vindo aprovar a sua aplicação analógica às sociedades anónimas ${ }^{15}$. Já as prestações acessórias são admitidas expressamente nas sociedades por quotas, anónimas e em comandita por acções (remissão do art. $478^{\circ}$ CSC]. Já quanto aos suprimentos, a doutrina vem admitindo a sua utilização nas sociedades anónimas e em comandita por acções como forma de financiamento.

As prestações suplementares são obrigações sociais que assentam num compromisso dos sócios com o interesse da sociedade, assumindo aqueles o risco de não serem reembolsados, caso não existam bens distribuíveis ou a sociedade tenha sido declarada insolvente ou a Assembleia-Geral não delibere favoravelmente a restituição das quantias atribuídas pelos sócios à sociedade a título de prestações suplementares.

Cremos que este regime não se apresenta adequado às sociedades anónimas, pois neste tipo de sociedades o sócio assume apenas o risco de perda do valor da sua entrada. Não existe nestas sociedades uma norma comparável ao art. $198^{\circ}$, que permita aos sócios responsabilizarem-se, ainda que limitadamente, pelas dívidas da sociedade. Se o legislador não quis admitir esta possibilidade nas sociedades anónimas, também dificilmente autorizaria que assumissem no contrato de

\footnotetext{
15 No sentido da sua admissibilidade, v. Paulo Olavo Cunha, Direito das Sociedades Comerciais. $5^{a}$ edição Coimbra; Almedina, 2015, p.294. No sentido da sua inadmissibilidade, v., por todos, Coutinho de Abreu, Curso de Direito Comercial. P. 302.
} 
sociedade a responsabilidade pela realização de prestações suplementares que fazem participar o sócios no risco do desenvolvimento da actividade da sociedade muito para além da perda do valor da sua entrada. Por outro lado, as prestações suplementares são historicamente um instrumento de financiamento privativo das sociedades por quotas.

Para contornar esta dificuldade, a prática empresarial tem-se socorrido da figura das prestações acessórias. Assim, se as condições de reembolso de empréstimo, que revestissem a natureza de uma prestação acessória, tornassem a restituição dependente do respeito pelo princípio da intangiblidade do capital social e da não ocorrência de declaração de insolvência, estariámos perante uma obrigação acessória sujeita neste domínio ao regime das prestações suplementares.

A preocupação que orienta o recurso à figura das prestações acessórias sujeitando-as quanto às condições patrimoniais de reembolso ao regime das prestações suplementares reside no aumento do capital próprio das sociedades.

Em homenagem do princípio da liberdade contratual, será possível tornar o reembolso dependente do respeito pelo princípio da intangibilidade do capital social e da inexistência de declaração de insolvência, no âmbito de acordos laterais do sócio com a sociedade. $\mathrm{Na}$ verdade, estes acordos produzem efeitos meramente obrigacionais, uma vez que apenas vinculam a sociedade e o sócio que concedeu 0 empréstimo.

Já parece duvidoso que tal possa acontecer no âmbito das prestações acessórias nas sociedades anónimas Com efeito, sendo as obrigações acessórias verdadeiras obrigações sociais, elas acompanham a transmissão das acções.

Nas sociedades anónimas, a responsabilidade de cada sócio limita-se ao valor da sua entrada. Trata-se de um elemento essencial deste tipo de sociedades, donde decorre que o accionista apenas assume o risco de perda do valor da sua entrada, somente nesta medida correndo o risco de exploração da sociedade.

$\mathrm{Na}$ realidade, resultam do art. $271^{\circ}$ do CSC, como características essenciais das sociedades anónimas, a ausência de responsabilidade 
dos accionistas pelas dívidas sociais e a limitação da responsabilidade de cada um pela realização da sua entrada.

Não existe, ao contrário do que sucede nas sociedades por quotas, a possibilidade de o estatuto social prever a responsabilidade de um ou mais sócios pelas dívidas da sociedade (ainda que limitada a um determinado valor]. Em conformidade, também a lei não contempla a possibilidade de o estatuto da sociedade contemplar a responsabilidade de um ou mais sócios pela realização de prestações suplementares. Tanto em um como em outro, caso o sócio corre o risco de exploração da sociedade de modo mais intenso.

Não arca, pois, no âmbito das suas obrigações sociais, com a responsabilidade pelas dívidas sociais, nem toma sobre si qualquer outra responsabilidade perante a sociedade que o faça correr o risco de exploração desta.

Transmitindo-se as obrigações acessórias em conjunto com as acções, o adquirente corre o risco de exploração da sociedade, não apenas no valor da sua entrada, mas igualmente pelo valor das quantias emprestadas, que só poderão ser restituídas se não atingirem as verbas necessárias aos valores do capital social e da reserva legal e não tiver sido declarada a insolvência da sociedade. Ao contrário do que sucede com os acordos laterais, estas condições impor-se-iam ao adquirente das acções, que não acordou a obrigação acessória de empréstimo com a sociedade.

Por outro lado, o regime das prestações acessórias está moldado pela ideia de que, se do cumprimento das obrigações acessórias advierem créditos para os sócios em relação à sociedade, estes serão tratados como credores (embora no âmbito dos suprimentos assumam o papel de um credor especial, mais comprometido com 0 interesse social ${ }^{16}$ ]. Não implicam pois as prestações acessórias que o sócio suporte o risco associado ao desenvolvimento da actividade social, com a amplitude das prestações suplementares.

16 Não deixam, no entanto, de ser credores e, por este motivo, o reembolso não terá necessariamente de se fazer à custa de bens distribuíveis. 
Pelos motivos expostos, parece que nada haverá a opor a que no âmbito de um empréstimo autónomo (seja ou não suprimento) entre um accionista e a sociedade as condições de reembolso incluam o respeito pelo princípio da intangiblidade do capital social e da ausência de declaração de insolvência. Contudo, parece ser de recusar a dependência nessas condições onde o empréstimo revista a natureza de uma obrigação social, como sucede no caso de assumir a qualidade de obrigação acessória.

\section{Tratamento em sede de imposto do selo dos suprimentos, das prestações acessórias e das prestações suplementares}

\subsection{O Imposto do Selo: considerações gerais}

Desde a reforma da tributação do património de 2003/2004 ${ }^{17}{ }^{18}$, o imposto do selo assumiu uma natureza dual, passando a decompor-se em duas espécies distintas de imposto do selo ${ }^{19}: \boldsymbol{a}$ ] imposto do selo propriamente dito, o tradicional, e b] imposto do selo sobre as transmissões gratuitas.

A primeira espécie de imposto do selo incide sobre os actos que, tradicionalmente, sujeitos ao imposto do selo (actos, contratos, títulos, papéis sujeitos a este imposto, nos termos da tabela geral do imposto do selo]. Já a segunda espécie de imposto do selo é um imposto que incide sobre bens concretos, ou individualmente considerados, ${ }^{20}$ transmitidos gratuitamente a favor de pessoas singulares.

Não admira, por isso, que, sem que haja uma dupla tributação, uma mesma situação jurídico-tributária possa integrar o âmbito de

\footnotetext{
17 Por meio da qual foi abolido o imposto específico sobre sucessões e doações e, parcialmente, incorporado no Imposto do Selo.

18 Sobre a origem e, uma breve, evolução histórica do Imposto do Selo em Portugal, v. J. L. Saldanha Sanches, Manual de Direito Fiscal, 3. ${ }^{\text {a }}$ ed., Coimbra Editora, Coimbra, 200?, pp. 431, ss..

19 No sentido de haver dois impostos no imposto do selo, vide José Casalta Nabais, Direito Fiscal, 8. ${ }^{a}$ ed., Almedina, Coimbra, 2015, p. 578.

20 E não sobre o património, globalmente considerado, como acontecia com o antigo Imposto sobre Sucessões e Doações.
} 
incidência normativa de ambos os impostos do selo, havendo então lugar a cumulação das duas espécies deste imposto ${ }^{21}$.

A este propósito, tenha-se presente que, nos termos do Preâmbulo ao Código do Imposto do Selo, consideram-se excluídas da sua incidência as transmissões patrimoniais gratuitas a favor de pessoas colectivas ["dos sujeitos passivos do imposto sobre o rendimento das pessoas coletivas"] ${ }^{22}$.

Merece ainda destaque o facto de a disciplina reguladora do Imposto do Selo se encontrar distribuída por dois códigos distintos, ainda que complementares: o Código do Imposto do Selo e a Tabela Geral do Imposto do Selo; o primeiro dispõe acerca da disciplina geral do imposto do selo e a segunda contém uma lista dos factos tributários concretamente sujeitos ao impostos do selo e as respectivas taxas.

Por fim, refira-se que, segundo o art. $1 .^{\circ}, 2$ do Código do Imposto do Selo [adiante, abreviadamente, designado "CIS"], não estão sujeitas a imposto do selo as operações sujeitas a imposto sobre o valor acrescentado (abreviadamente, "IVA") e dele não isentas.

\subsection{A exclusão de tributação em sede de imposto do selo nas entra- das no capital social}

A verba 26 da tabela geral do imposto do selo, que sujeitava a tributação em sede deste imposto as entradas de capital, foi revogada pelo art. 99. ${ }^{\circ}, 2$ da Lei n. ${ }^{0} 3-B / 2010$, de 28 de abrill ${ }^{23}$, que aprovou 0 Orçamento do Estado para 2010.

Esta revogação ocorreu na sequência do entendimento sufragado pelo Tribunal de Justiça das Comunidades Europeias, no acórdão de 21 de junho de 2007, proferido no âmbito do Processo C-366/05, nos

\footnotetext{
${ }^{21}$ Tal acontece no caso de transmissão gratuita de bens sujeitos a imposto do selo sobre a transmissão gratuita $(10 \%)$ e ao imposto do selo propriamente dito $(0,8 \%)$, de acordo com as verbas 1.1 e 1.2 da tabela geral do imposto do selo. Cfr. ainda art. $1 .^{\circ}, 4 \mathrm{CIS}$.

22 Transmissões essas que passam a integrar, na qualidade de incrementos patrimoniais, o conceito de "variações patrimoniais positivas do lucro" ou de "rendimento global", consoante estejamos perante empresas colectivas ou pessoas colectivas que não são empresas.

${ }^{23}$ Com entrada em vigor no dia seguinte ao da sua publicação, de acordo com o art. $176 .{ }^{\circ}$ do referido diploma.
} 
termos do qual se considerou que a então verba 26.3 da tabela geral do imposto do selo era contrária ao direito comunitário, por violação do disposto no art. 7. ${ }^{0}, 1$ da Diretiva 69/335/CEE, do Conselho de 17 de julho de 1969, relativa aos impostos indiretos que incidem sobre as reuniões de capitais, na redação que Ihe foi dada pela Diretiva 85/303/ CEE, do Conselho, de 10 de junho de 1985. A interpretação defendida pelo Tribunal neste aresto, ainda que se circunscrevesse, quanto aos efeitos diretos, apenas à verba 26.3, acabava por ter um alcance geral sobre toda a verba 26 , facto que, em boa medida, determinou a solução revogatória seguida, em 2010, pelo legislador português ${ }^{24}$.

Fruto dessa revogação, as entradas de capital deixaram de ser objecto de imposto do selo, o que tem funcionado como um incentivo fiscal à constituição de sociedades comerciais ou eventuais aumentos de capital por novas entradas ${ }^{25}$, qualquer que seja o bem com que é efetuada a entrada.

\subsection{0 enquadramento dos suprimentos, prestações suplementares e acessórias no Código do Imposto do Selo}

De acordo com o disposto na al. f) do n. ${ }^{\circ} 3$ do art. 1 do CIS, "[p] lara efeitos da verba 1.2 da Tabela Geral, são consideradas transmissões gratuitas, designadamente, as que tenham por objecto:

$[\ldots]$

f) Direitos de crédito dos sócios sobre prestações pecuniárias não comerciais associadas à participação social, inde-

\footnotetext{
24 Pugnando pela desconformidade desta verba 26, na sua totalidade, com o Direito Comunitário pronunciavam-se já António Castro Caldas e Filipe Romão, Imposto do Selo - Desconformidade da Verba 26 da Tabela Geral do Imposto do Selo com o Direito Comunitário, 2009, publicado em

http://www.uria.com/pt/oficinas/lisboa/abogados.html? iniciales=FRR\&seccion=publicaciones\&cid=2180\&pub=Publicacion

25 Mesmo antes desta alteração legislativa, já se considerava que os aumentos de capital por incorporação de reservas se encontravam não sujeitos a imposto do selo. Assim também, a informação vinculativa das Administração Fiscal de 2009, disponível em http://info.portaldasfinancas.gov.pt/NR/rdonlyres/958F0A20-206A-44B4-BAE2-DCA19EAA3274/0/__Selo-V_26.pdf
} 
pendentemente da designação, natureza ou forma do acto constitutivo ou modificativo, designadamente suprimentos, empréstimos, prestações suplementares de capital e prestações acessórias pecuniárias, bem como quaisquer outros adiantamentos ou abonos à sociedade".

Assim descrita a questão, seríamos tentados a concluir, porventura prematuramente, que os empréstimos, em geral, e os suprimentos, as prestações suplementares de capital e as prestações acessórias pecuniárias estariam, sempre, sujeitas ao pagamento do imposto do selo.

Porém, esta norma tem que ser interpretada com alguma prudência. Efetivamente, em primeiro lugar, ela parece referir-se aos direitos de crédito dos sócios (que sejam pessoas singulares] emergentes daquelas prestações pecuniárias e que sejam por estes transmitidos a título gratuito a outrém; e, em segundo lugar, decorre claramente do Preâmbulo ao CIS que as pessoas colectivas não estão sujeitas a imposto do selo sobre transmissões gratuitas que Ihes sejam feitas: as transmissões serão tributadas em sede de IRC. Por conseguinte, apenas as pessoas singulares se encontrarão, aparentemente, sujeitas ao pagamento de imposto do selo no caso de transmissões gratuitas.

Com efeito, declara-se no preâmbulo que

"[t]ambém se excluem da incidência do imposto as transmissões gratuitas a favor dos sujeitos passivos do imposto sobre o rendimento das pessoas colectivas.

Esta exclusão, que representa outra das alterações profundas da reforma, vem reafirmada nas normas de incidência subjectiva em que só as pessoas singulares passam a ser sujeitos passivos deste imposto.

Por esta via, introduz-se um princípio de maior coerência no sistema tributário, no sentido da concretização do conceito de rendimento acréscimo consagrado no Código do IRC, já que todos os afluxos patrimoniais que ingressem na esfera jurídico-patrimo- 
nial das pessoas colectivas ou equiparadas passarão a relevar para efeitos da determinação da sua matéria colectável.

A sujeição destas transmissões a IRC não prejudica, porém, as eventuais isenções ou exclusões em sede desse imposto, que agora passarão igualmente a incluir os ingressos patrimoniais que tinham idênticos benefícios em sede de imposto sucessório."

Não é, pois, por aqui que, em princípio, resolveremos o nosso problema. Até porque a norma contida no al.f) do n. ${ }^{\circ} 3$ do art $1 .^{\circ} \mathrm{CIS}$ nos parece ser de alcance muito duvidoso, quer quanto ao conceito-base de "transmissão gratuita" que lhe está subjacente, quer quanto à inserção de alguns destes atos jurídicos nesse conceito, quer mesmo quanto à aplicação, nesses casos, da verba 1.2 da tabela geral.

\subsubsection{0 imposto de selo no caso de suprimentos}

Este problema é, pelo menos em parte, resolvido, pela negativa, na al. i], do n. 1 do art. 7. ${ }^{\circ}$ CIS. Nessa norma estabelece-se uma isenção (de carácter objectivo) de imposto do selo nos casos de

"empréstimos com características de suprimentos, incluindo os respetivos juros, quando realizados por detentores de capital social a entidades nas quais detenham diretamente uma participação no capital não inferior a $10 \%$ e desde que esta tenha permanecido na sua titularidade durante um ano consecutivo ou desde a constituição da entidade participada, contando que, neste caso, a participação seja mantida durante aquele período".

Trata-se de uma norma antiga, mas cuja redação atual foi, recentemente, alterada pelo Orçamento de Estado para 2016 (Lei n. ${ }^{0}$ 7-A/2016, de 30 de março, com entrada em vigor no dia seguinte ], no sentido de limitar a isenção de imposto do selo neste tipo de operações financeiras.

De facto, a redação anterior desta norma estipulava uma isenção com contornos bem mais amplos do que atualmente se prescreve. 
De acordo com a anterior versão deste normativo, ficavam isentos de imposto do selo

"os empréstimos com características de suprimentos, incluindo os respectivos juros efectuados por sócios à sociedade",

pelo que em nada influía nessa isenção a percentagem de capital social detido pelo sócio que realizou o suprimento, por exemplo.

0 intuito limitador do alcance da isenção de imposto do selo sobre os suprimentos no novo preceito legislativo foi, por isso, claro. Nesse sentido, apenas haverá isenção de imposto no caso de se verificarem, em concreto e cumulativamente, as seguintes circunstâncias:

a) Serem os empréstimos realizados por sócios que sejam titulares ou detentores, de forma direta, na sociedade beneficiária do empréstimo, de uma percentagem do capital social igual superior ou a $10 \%$;

b) Tais empréstimos têm que revestir as características próprias ou específicas dos suprimentos (com destaque, designadamente, para o carácter de permanência - do qual constitui índice ou presunção legal a estipulação de duração, ou prazo de reembolso, superior a um ano); e

c) Aquela participação social tem que ter estado na titularidade desse sócio durante um ano consecutivo ou, no caso de a sociedade na qual detém esse capital ter sido constituída há menos de um ano, essa participação terá que ser mantida durante o período de um ano consecutivo, contado da constituição da sociedade ${ }^{26}$.

Perante a imprecisão terminológica e a formulação linguística adotada nesta disposição legal, devemos confessar algumas dúvidas

\footnotetext{
26 Constituindo-se a obrigação tributária no momento em que o suprimento for realizado (cfr. art. $5 .^{\circ}, 1, g$ ) CIS ) e devendo o imposto ser pago até ao vigésimo dia do mês seguinte àquele em que a obrigação tributária se constituiu (cfr. art. $44 .^{\circ}, 1 \mathrm{CIS}$ ), não se vislumbra muito bem como poderá, com efetividade, a Autoridade Tributária sindicar o cumprimento do requisito da permanência posterior do sócio numa percentagem superior a 10\% do capital social.
} 
interpretativas quanto ao real sentido e alcance do disposto no art. 7. $\left.{ }^{\circ}, 1, i\right]$, in fine CIS, que corresponde a este terceiro requisito supra referenciado. Apesar de a interpretação que consideramos mais adequada, atento o texto da lei e a sua coerência intra-sistemática (cfr. art. 9. ${ }^{\circ}$ CC), ser aquela que ficou anteriormente exposta no requisito da al. c], admitimos, porém, como possível a interpretação de que a parte final deste normativo se dirige a sociedades coligadas em relação de participação (nos termos dos arts. $481 .^{\circ}$, ss. do Código das Sociedades Comerciais [adiante, abreviadamente, designado por "CSC"]), sendo o intuito da expressão "entidade participada" o de, precisamente, abranger essas sociedades coligadas, sujeitando-as a uma limitação adicional: sendo o suprimento concedido por uma sociedade a outra sociedade com ela coligada, aquele ato jurídico só estaria isento de imposto do selo no caso de a sociedade concedente deter participação no capital da sociedade beneficiária (participada) igual ou superior a 10\%, desde a sua constituição e essa participação ser mantida durante, pelo menos, um ano consecutivo. ${ }^{27}$

Para que se verifique esta isenção parece, além do mais, determinante que se verifique o carácter de permanência do suprimento, pois constitui característica própria dos suprimentos o facto de se tratarem de i] empréstimos concedidos pelos sócios à sociedade ii] a médio/longo prazo (o que a lei presume, de forma ilidível ou afastável, quando o prazo estipulado de duração do suprimento for superior a um ano, nos termos dos n. ${ }^{\circ} 2$ e 3 do art. $243 .^{\circ}$ CSC ]. É por essa razão que os suprimentos assumem um carácter de financiamento da sociedade supletivo do (financiamento feito pelo) capital social.

Uma questão que então se pode levantar é a de o financiamento ser concedido por meio de um empréstimo de curto prazo, para cober-

\footnotetext{
27 Uma outra dúvida interpretativa poder-se-ia colocar a propósito do prazo de detenção da participação na hipótese final da norma ["contando que, neste caso, a participação seja mantida durante aquele período"]. "Aquele período" será o período de um ano simples, anteriormente referido para a primeira hipótese, ou o período de duração do suprimento? Seguimos a posição vertida em texto, no requisito da al. c), por nos parecer mais adequado à formulação linguística do preceito e porque, por vezes, o sócio poderá renunciar ao reembolso do suprimento, o que esvaziaria de conteúdo útil uma tal interpretação.
} 
tura de carências de tesouraria. Saber se será este um contrato de suprimento ou, antes, um simples mútuo (regulado pelos arts. 1142. ss. CCivil) ou um empréstimo mercantil (regulado pelos arts. 394. ${ }^{\circ}$ CComercial] é questão controvertida, embora relevante.

Surge, ainda, um problema adicional, relacionado com o disposto no art. $5 .^{\circ}, 1, m$ ] CIS. Com efeito, resulta desta disposição que tratando-se de empréstimo efectuado pelos sócios às sociedades em que seja estipulado prazo igual ou superior a um ano, mas em que ocorra reembolso antes desse prazo (devendo, cremos, aqui entender-se que a expressão "antes desse prazo" se refere ao prazo de "um ano", e não ao prazo que, voluntária e casuisticamente, estipulado, sob pena de possível desigualdade de tratamento fiscal dos contribuintes e de indeterminabilidade do preceito legal ${ }^{28}$ ), a obrigação tributária constitui-se no momento do reembolso, sendo, pois, nesse momento devido o pagamento do imposto de que outrora se encontrava isento. Quid iuris, então, se o empréstimo for efectuado pelos sócios às sociedades em que seja estipulado prazo não inferior a um ano, mas em que aqueles sejam reembolsados antes desse prazo?

Em qualquer dos dois casos precedentes, mesmo considerando que o financiamento foi feito pelo sócio à sociedade com o objectivo de fazer face a carência (transitória) de tesouraria, entendemos que tais operações pode também beneficiar da isenção de imposto do selo, nos termos conjugados das als. h] e g) do n. ${ }^{0} 1$ do art. ?. ${ }^{\circ}$ do CIS, porquanto resulta da interpretação conjunta dessas disposições que

as operações financeiras, incluindo os respectivos juros, por prazo não superior a um ano, desde que exclusivamente destinadas à cobertura de carências de tesouraria, quando realizadas por detentores de capital social a entidades nas quais detenham diretamente uma participação no capital não inferior a $10 \%$ e desde que esta tenha permanecido na sua titularidade durante

\footnotetext{
280 que se encontra proibido constitucionalmente pela consagração do princípio da legalidade fiscal, na vertente material da tipicidade ou determinabilidade, (decantado do art. 103. 2 da Constituição da República Portuguesa [adiante, abreviadamente, designada por "CRP"]) e pelo princípio da igualdade fiscal (cfr. art. $13 .{ }^{\circ} \mathrm{CRP}$ ).
} 
um ano consecutivo ou desde a constituição da entidade participada, contanto que, neste último caso, a participação seja mantida durante aquele período.

Não preenchendo a situação a previsão normativa de qualquer destas normas de isenção da incidência do imposto, será devido, nestes casos, imposto do selo por tais operações financeiras. Daqui resulta então que, nos termos da verba 17 da tabela geral do imposto do selo, especialmente nas verbas 17.1 .2 e 17.1.3, que haverá lugar ao pagamento do imposto do selo - à taxa de 0,05\% ou 0,06\%, calculada sobre o valor do empréstimo, consoante estejamos perante um suprimento constituído por prazo igual ou superior a um ano ou em face de um suprimento celebrado por prazo igual ou superior a cinco anos - sempre que os suprimentos sejam efectuados por sócios que detêm menos de $10 \%$ do capital social ou naquelas situações em que o sócio detentor de participação igual ou superior a 10\% do capital social não preencha o requisito temporal de detenção dessa participação, exigido no art. ?. $^{\circ}, 1$, i] CIS.

No caso de se tratar de um empréstimo de curto prazo, cujo prazo seja inferior a um ano, seja ele um simples mútuo (civil ou mercantil) ou um suprimento, que, embora celebrado por prazo superior, seja reembolsado em menos de um ano, será aplicável, nos termos da verba 17.1 .1 da tabela geral, uma taxa de $0,04 \%$, sobre o respectivo valor, por cada mês ou fração.

\subsubsection{0 imposto de selo no caso de prestações suplementares e obrigações acessórias}

Relativamente às prestações suplementares e às obrigações acessórias, o código do imposto do selo é omisso no seu tratamento, afora a referência efectuada no, já citado, art. $1 .^{\circ}, 3, f$ ), referente à verba 1.2 da tabela geral, e não à verba 17 da mesma tabela.

Não obstante esse facto, pensamos que quer as prestações suplementares (que não podem vencer juros e, por isso, são atos gratuitos - cfr. art. 210. ${ }^{\circ}, 5$ CSC] quer as prestações acessórias, sejam 
estas gratuitas ou onerosas (cfr. art. 209. ${ }^{\circ}, 1$ CSC), enquanto operações financeiras que são, estão sujeitas a imposto do selo, nos termos da verba 17.1 da tabela geral do imposto do selo, dependendo a taxa do prazo estabelecido, nos termos anteriormente analisados.

A grande diferença destas formas de financiamento societário em relação aos suprimentos residirá, em nossa opinião, no facto de não Ihes serem aplicáveis as isenções previstas em lei para os empréstimos e suprimentos. Admitimos, contudo, numa interpretação lata do conceito de "operações financeiras", que estas obrigações acessórias e suplementares possam encontrar-se cobertas pela isenção normativa de incidência do imposto do selo nos casos previstos nas als. $g$ ) e h) do n. ${ }^{0} 1$ do art. 7. ${ }^{\circ} \mathrm{CIS}$. Em todo o caso, o seu âmbito de aplicação é, como vimos, muito limitado.

Esta diferença de tratamento acaba por resultar num tratamento fiscal muito mesmo favorável destas obrigações em relação aos suprimentos e empréstimos em geral, com claro prejuízo (mais um no domínio deste imposto] para a tão almejada neutralidade fiscal.

\subsection{Sobre quem recai o encargo do pagamento do imposto e compe- tência de liquidação do imposto}

De acordo com o disposto no art. 3. ${ }^{\circ}, 1$ CIS

"[o] imposto constitui encargo dos titulares do interesse económico nas situações referidas no artigo 1. ."

Concretiza-se, posteriormente, na al.f) do n. ${ }^{0} 3$ do art $3 .{ }^{\circ} \mathrm{CIS}$ que, para efeitos daquela norma, se considera titular do interesse económico no caso de concessão de crédito o "utilizador do crédito", que, in casu, é a sociedade comercial beneficiária do empréstimo, do suprimento ou da obrigação suplementar ou acessória ${ }^{29}$. 
Por seu turno, a liquidação do imposto do selo compete aos sujeitos passivos referidos nos n..$^{\text {os }} 1$ e 3 do art. $2 .{ }^{\circ} \mathrm{CIS}$, ex vi art. $23 .{ }^{\circ}$, sendo também de realçar a responsabilidade tributaria solidária estatuída no art. $42 .^{\circ} \mathrm{CIS}$, em que podem incorrer, entre outros, advogados e contabilistas certificados, no caso de falta de colaboração com os sujeitos passivos na liquidação do imposto devido.

\subsection{Constituição da obrigação tributaria e prazo de pagamento}

Segundo o disposto na al. g) do n. ${ }^{0} 1$ do art. $5 .{ }^{\circ} \mathrm{CIS}$, tratando-se de operações de crédito, a obrigação tributaria de selo considera-se constituída, ou seja, nasce, no momento em que tais operações forem realizadas.

Todavia, é importante não esquecer que a lei consagra uma regra especial, na al. $m$ ) do n. ${ }^{0} 1$ do art. $5 .^{\circ} \mathrm{CIS}$, para o caso dos

"empréstimos efetuados pelos sócios às sociedades em que seja estipulado prazo não inferior a um ano e sejam reembolsados antes desse prazo",

hipótese em que a obrigação se constitui no momento do reembolso.

Esta última disposição só se compreende se for interpretada conjuntamente com as isenções estudadas no art. 7. ${ }^{\circ} \mathrm{CIS}$, sob pena de não parecer adequar-se devidamente com o disposto no art. $5^{\circ}, 1$, g) CIS. Ou seja, esta disposição aplica-se aos casos em que estando a operação isenta de imposto e passa, por este facto, a estar a ele sujeita, sendo necessário determinar o momento em que o imposto é devido.

Por último, o imposto deve ser pago, nos termos dos arts. $43 .^{\circ}$ e $44 .^{\circ} \mathrm{CIS}$, mediante documento de cobrança de modelo oficial, nas tesourarias de finanças ou noutros locais permitidos por lei (como pagamento por via electrónica) até ao dia 20 do mês seguinte àquele em que a obrigação tributária se tenha constituído.

temporário] a favor das sociedades comerciais (que são pessoas coletivas) delas beneficiárias. 
